\title{
A VIOLÊNCIA, A FIGURA FEMININA INDÍGENA E A CALIGRAFIA DE DEUS, DE MÁRCIO SOUZA
}

\section{THE VIOLENCE, THE INDIGENOUS FEMALE FIGURE AND THE CALLIGRAPHY OF GOD, BY MÁRCIO SOUZA}

\author{
Cacio José Ferreira ${ }^{1}$
}

Norival Bottos Júnior ${ }^{2}$

Recebido em: 18 jun. 2020

Aceito em: 30 set. 2020.

DOI: 10.26512/aguaviva.v5i3.32156

RESUMO: Este artigo discute a temática da mulher indígena no estado do Amazonas a partir do arcabouço teórico advindo das relações de gênero, de feminicídio e diáspora no texto $A$ Caligrafia de Deus (2007), de Márcio Souza. A narrativa expõe o modo como a mulher indígena é submetida a uma intricada rede de articulações de poder e de patriarcado. Dessa forma, são evidenciadas como as relações de gênero dão vazão à posse do corpo e da mente do "outro" e de como as relações de poder surgem a partir das questões de gênero, sobretudo, por meio da cultura, que se torna historicamente modificada na episteme contemporânea por novas articulações de controle e de exercício de dominação.

Palavras-chave: Violência. Mulher indígena. A caligrafia de Deus. Amazônia.

ABSTRACT: This article discusses an issue of indigenous women in the State of Amazonas from the advanced theoretical framework of gender relations, feminicide and diaspora in the text A Caligrafia de Deus (2007), by Márcio Souza. A narrative exposes the way an indigenous woman is subjected to an intricate network of articulations of power and patriarchy. In this way, it is evident how gender relations give rise to the possession of the body and mind of the "other" and how power relations arise from gender issues, especially through culture, which becomes historically modified in the contemporary episteme by new articulations of control and exercise of domination.

Keywords: Violence. Indigenous woman. The Calligraphy of God. Amazon.

\footnotetext{
1 Doutor em Literatura e professor da Universidade Federal do Amazonas (UFAM). E-mail: caciosan@ufam.edu.br

${ }^{2}$ Doutor em Letras e Estudos Literários e professor da Universidade Estadual do Mato Grosso do Sul (UEMS). Email: nonobottos@gmail.com
} 


\section{INTRODUÇÃO}

Qualquer que seja a possibilidade que o sentido histórico, que a essência de um determinado momento exige, e o nosso parece exigir apenas o "rastro", termo que Jacques Derrida (2011) define como a necessidade de seguirmos por trilhas sem a esperança de depararmo-nos com o ponto central ou o ponto de origem, o que nos resta então, é pensar a literatura e a história como trilhas indefinidas, construídas a partir de lacunas que o testemunho da memória e da imaginação deixa para trás, brechas em floresta densa.

Os interstícios que buscaremos pensar a respeito do horror causado pelas relações de poder, e que são possivelmente causados pelos problemas de gênero e impressos, principalmente, em corpos femininos, principalmente de sociedades marginalizadas, que resultam em efeitos sociais e políticos que em nossos tempos denominamos, não sem certo incômodo epistemológico, de neocolonialismo.

No caso deste artigo, interessa pensar esses efeitos na região amazônica, num sentido que se aproximaria sempre da epistemologia do "rastro", do "fora" e da "aporia" de Jacques Derrida $(2011 ; 2002)$, e exposto como principal fundamento de seu pensamento filosófico o poder que a contemporaneidade pode reservar ao processo de deslocamento das forças do passado em proveito de novas rearticulações, estas, muito mais ligadas a um questionamento das formas contemporâneas de exclusão.

Para o pensador franco-argelino, é preciso apontar para o horizonte em que as simples categorias binárias de oposição não façam mais sentido. As oposições não desaparecem com o estatuto da différance, porém, o dado positivo desse método é que a falsa aparência de positividade é implodida a partir de dentro da própria enunciação.

Nessa perspectiva, a diferença dos polos opositivos em termos sexuais, antropológicos, metafísicos, estéticos, enfim, todas as formas de relação cultural, estão crivadas no privilégio natural de certos termos, como "masculino" como sendo positivo, e "feminino", como negativo, e que não se opõe naturalmente, mas sim culturalmente. São antinomias construídas para a preservação de certos privilégios de um grupo dominante sobre outros grupos. Nenhum começo é justificável, o como se, de Jacques Derrida traz a costura do começo à mostra, desvelando o jogo da différance que, sem pouca dificuldade, se adéqua ao formato que o começo lhe impõe.

Àquele que é facultada a tarefa de perscrutar o passado com o olhar da crítica institucionalizada deve do mesmo modo estender sua visagem para os efeitos desses rastros do 
passado naquilo que se manifesta no presente de modo mais problemático, que é seu conteúdo que se nos apresenta como efeito metafórico e, portanto, de assimilação bastante problemática. Neste sentido, este artigo empreende uma reflexão, ainda que muito simples e provisória do que hoje podemos interpretar a respeito das consequências do neocolonialismo sobre o corpo e a mente de mulheres indígenas. Nosso corpus é baseado na breve obra de ficção, A caligrafia de Deus (2007), conto de Márcio Souza.

Partindo da ideia de que o horror político é antes de tudo uma questão de gênero e de como ela se articula por meio da linguagem, nosso enfoque se limitará ao modo como o gênero e sua desconstrução permitem a observação de diferentes instâncias fundadoras de intencionalidades de produção de subjetividades. Dessa forma, discutiremos o feminicídio, a diáspora e seus efeitos.

Nessa esteira, analisar diferentes construções de sujeito e modos de como as construções identitárias se exprimem ou se calam, tanto nos espaços de exclusão do mundo amazônico como nos confins dos subúrbios de Manaus, significa deixar de lado o caráter universal, que Rita Laura Segato denomina de "espaço neutro do sujeito republicano, onde supostamente fala o sujeito cidadão universal. Tudo o que sobra nesse processo, o que não pode converter-se ou equiparar-se dentro dessa grade equalizadora, é resto" (SEGATO, 2012, p. 123). Por fim, o texto faz uma reflexão sobre as perspectivas que sejam capazes de se opor ao caráter políticoestético do horror moderno nessas sociedades. Dessa maneira, evidenciamos o fato de que o capital cultural da história possui um excesso que transborda dos registros acumulados ao longo dos séculos e que não mais pertencem à economia da linguagem daquilo que está sendo narrado em nome do "outro" na história.

\section{A figura indígena feminina em A caligrafia de deus, de Márcio Souza}

A natureza da contemporaneidade não pode ser definida para além de um cipoal de presentes e passados, quase sempre sem conexão aparente. A contemporaneidade está, portanto, ligada ao paradoxo do "ex-cêntrico" derridiano, que é a manifestação de tudo que sempre esteve fora. Simbiose do que há de mais poroso, livre do centro, expressão do mundo centrífugo do colonizador e sem um começo, capaz de devolver ao colonizado a força centrípeta do pensamento do "outro", incapaz, assim, de reabilitar a noção dialética do binarismo e da essência original das coisas em si mesmas. Nesse caminho, Edward Said aborda a relação conflituosa do passado e seus efeitos no presente nos seguintes termos: “[...] a maneira como 
formulamos ou representamos o passado molda nossa compreensão e nossas percepções do presente" (SAID, 2011, p. 36).

Said nos alerta em relação ao perigo do qual não sejamos capazes de inocularmo-nos das próprias formulações do passado, de não nos atentarmos para os perigos de pensar o passado como um “foi assim”, tão combatido por Derrida (2011; 2002), que julgava o projeto filosófico voltado para a instância contrária, ou seja, substituindo o caráter delusório do "foi assim" pelo rastro do "se" repetido indefinidamente. O "se" responderia como efeito catalizador de novas metáforas que substituiriam o hiato deixado pelo pensamento imperialista que o passado nos revogou como a forma de se pensar a si e ao outro. Sendo assim, há preocupação em manter, sob a luz da crítica, todo o complexo de forças múltiplas que delimitam o antigo imperialismo europeu e sua influência ao redor do mundo, mas no caso em especial deste artigo, em seus efeitos sobre o mundo amazônico.

No século dezenove, o positivismo fora elevado ao paroxismo e lançado, por meio de múltiplas bases para os mais diversos campos, nas ciências humanas, biológicas, nas artes vide toda a gigantesca produção romanesca europeia sobre o exotismo do mundo não europeu produzidos entre os séculos dezoito e dezenove, - essa visão assimétrica hoje se vê reeditada, reabilitada em nome dos mesmos motes progressistas, porém, agora intitulados de "globalização" de "neoliberalismo", sob a ótica política e econômica de poder sobre o "outro".

O conceito de gênero na pós-modernidade só pode ser pensado como uma dinâmica contínua e anacrônica. No vácuo das questões identitárias há uma questão que por si só pode desencadear uma longa série de proposições que ora se tocam, tergiversam e se afastam indefinidamente. Uma delas, é a memória da diáspora. No caso amazônico, há um complexo sistema de ruínas deixadas pela presença do colonizador. Tal fato causa uma série quase infindável de ações predatórias.

O que é a memória para o homem amazônico, seja ele um branco, um caboclo ou um índio? Quais as características traumáticas das diásporas de cada um deles? Como a diáspora nos diz sobre o fracasso do projeto civilizador nessa região? Como você se apresenta ao outro? Acreditamos que estas questões só têm validade se considerarmos que são fruto direto de agenciamentos e de estratégias contemporâneas de opressão bem articuladas de modo social e político, mas, cujo centro, sempre se desloca de uma margem para outra sem nunca deixar de ser centro. O processo das diásporas e dos deslocamentos incessantes efetiva-se menos por necessidades físicas do que questões de dominações “outras", como a dominação do espaço do corpo no mundo cultural, por exemplo. Esta diáspora causa diferença, disjuntiva por excelência, 
é o que Stuart Hall (2013) designa como não mais sendo o lugar de pertencimento ou de origem, mas de fabricação de um "outro", uma fabricação incessante.

Márcio Souza, nascido em Manaus, busca por meio de seus leitmotivs (Manaus e o Amazonas) os itinerários ficcionais capazes de desestabilizar e tornar problemáticas a manutenção dos binarismos do mundo colonizador e neoliberal. Sua obra evidencia o que há de aparentemente inconfundível na escrita linear da história do Amazonas. Em A caligrafia de deus (2007), o que sobressai é o esboroamento da interação - sempre forçada e desigual - entre os valores nativos e os valores colonialistas. E Manaus é o centro que se desloca incessante nas vidas configuradas e reconfiguradas pela colonização. Manaus foi construída como uma espécie de "muro", separando as frações civilizadas do mundo da floresta, desagregando o "eles", os selvagens de "nós", os civilizados, revitalizando a mesma dicotomia observada em romancistas do século XIX, como Kipling, Defoe ou Conrad. De modo análogo, o desmanche dos propósitos exploratórios que se observou no resto do mundo também deixou suas marcas, suas frinchas que se espalham rizomaticamente em um universo tão rico quanto miserável em todos os sentidos na Amazônia. É importante, a partir do que foi dito sobre gênero, compreender talvez o seu efeito mais devastador, denominado por Rita Laura Segato (2012)como "feminicídio":

A rapinagem sobre o feminino se manifesta tanto sob as formas de destruição corporal sem precedentes, como sob as formas de tráfico e comercialização de tudo o que estes corpos podem oferecer, até ao seu limite. A ocupação depredadora dos corpos femininos ou feminizados se pratica como nunca até aqui e, nesta etapa apocalíptica da humanidade, espolia até deixar somente restos (SEGATO, 2012, p. 108).

A impunidade do feminicídio é reproduzido interminavelmente. Neste sentido, falar especificamente do ponto de vista do corpo feminino como território reinventado pela soberania do patriarcalismo, significa falar também do horror da colonização - e da neocolonização - de povos indígenas, porque o mundo-aldeia, metaforicamente pode ser entendido como o lado feminino da história, ao passo que o mundo colonial, articulado em torno da dominação do "outro" que é evidentemente inferior, pode ser percebido pela forma expressiva da dominação masculina. Mas quais são suas causas? Que resíduos esse processo deixa no território dominado? Acreditamos que o texto de Segato (2012) nos oferece o caminho:

[...] Ordem pré-intrusão, dobra fragmentária que convive conseguindo manter algumas características do mundo que antecedeu a intervenção colonial, mundo-aldeia: nem palavras temos para falar deste mundo que não devemos descrever como pré-moderno, para não sugerir que se encontra simplesmente 
no estágio anterior da modernidade e marcha inevitavelmente em direção a ela. Trata-se de realidades que continuarão caminhando, [...] junto e ao lado do mundo sob intervenção da modernidade colonial. Mas que, de alguma forma, ao serem alcançadas pela influência do processo colonizador, primeiro metropolitano ultramar e depois republicano, foram prejudicadas, particularmente em um aspecto fundamental: exacerbaram e tornaram perversas e muito mais autoritárias as hierarquias que já continham em seu interior - que são basicamente as de status, como casta e gênero (SEGATO, 2012, p. 114).

O horror como resultado dos diversos agenciamentos do corpo da mulher indígena pode ser entendido como feminicídio; o silêncio desse ato de violência extrema surge como forma única de reação ou sobrevivência, a alienação pela quietude, o "rastro" possível de insubordinação ou de mímese paródica do discurso do "outro".

O rastro inicial do feminicídio é a figura do Pai, o elemento dominador e colonizador por excelência nas mais diversas narrativas que têm o horror como tema, seja físico, psíquico ou uma mistura de ambos.

Qualquer experiência humana, individual ou coletiva, qualquer coisa que diga respeito aos negócios são questões públicas. As formas de poder e seu gerenciamento são normativas por natureza, mas só é política se recuarmos um pouco mais em busca da natureza mais íntima. Nela encontraremos o problema do gênero como catalisador natural dessas negociações. Para Blasius (1994), “a sexualidade é um lugar no qual o poder é exercido e um método pelo qual cada indivíduo constitui a si mesmo como conteúdo político: a sexualidade é política" (BLASIUS, 1994, p. 10). O caso específico da mulher, como agente político capaz de defender sua posição ao longo do percurso histórico pode se transformar numa questão tão nebulosa quanto contraditória, mas na história recente da humanidade, parece bastante evidente que o gênero feminino responde por dinâmicas que se concentram no modo como conseguem travar o embate pela sobrevivência, geralmente pelo viés cultural, mas também, em alguns casos, por algum tipo de ato de revolta - lembremos, como exemplo literário, a obra A greve do sexo, de Lisístrata. Há, no caso específico de comunidades indígenas, o silêncio, sendo é uma categoria de mecanismo, que também está apta a estabelecer algum ato de revolta contra o sistema opressor do gênero oposto e, em geral, se apresenta inicialmente na figura do "Pai". De acordo com Maria Izilda S. de Matos (2000), é sobretudo, uma questão de gênero.

[...] a influência mais marcante para essa abertura [dos estudos de gênero] parece ser a descoberta do político no âmbito cotidiano, o que levou a um questionamento sobre as transformações da sociedade; o funcionamento da família; o papel da disciplina e das mulheres; o significado dos fatos, lutas e 
gestos cotidianos. Assim, a expansão dos estudos sobre a mulher vinculou-se a uma redefinição do político, frente ao deslocamento do campo do poder das instituições públicas e do Estado para a esfera do privado e do cotidiano (MATOS, 2000, p. 11).

A reação contra os agenciamentos pode colocar a perder não só a permanência do indivíduo no grupo, mas, principalmente, o governo de si, como Michel Foucault $(2014 ; 1990)$ observa a respeito do estatuto da loucura na Idade Média até a modernidade. Neste caso, o poder exerce ampla e eficiente forma de coerção. São tecnologias das mais variadas, mas obviamente prontas a exercer o controle sobre o "outro", dominação que atua no desfecho do agenciamento que tem acesso a maneira da coletividade se constituir e como ela constitui os seus "indivíduos".

No processo de dominação pela linguagem, a obediência de um membro do grupo é relacionada à sua própria consciência - que é uma formação discursiva. É nesse jogo que o espaço de enunciação de narrativas evidencia a consciência modelada por relações assimétricas, seja em qualquer tipo de comunidade imaginada. Também é um jogo duplo, pois se alguém julga a si mesmo, delibera a partir de valores que pertencem ao "outro".

Contudo, o processo de dominação não pode ser confundido com o estatuto da violência física. Sendo maior grau de sofisticação, este atuará de modo relegar a segundo plano a violência física, o constrangimento físico. Assim, dominar o "outro" pressupõe que o jogo da influência não se esgote num continuum de coerções, mas sim em fazer com que o "outro" se sinta até certo ponto livre para agir, e principalmente, para se deslocar, para se desenraizar, revelando o processo moderno e mais eficiente de dominação.

Na literatura contemporânea, os personagens marginalizados geralmente anseiam por liberdade, permitindo facultar algumas escolhas e ações que podem se relacionar pragmaticamente com o exercício de poder daqueles que moldam os processos de subjetivação.

A discussão da dominação, do poder e da violência contra a mulher indígena, processos de subjetivação, responde de maneira dúbia, enviesada, não raramente contraditória. $\mathrm{O}$ problema de gênero e seus efeitos políticos e econômicos estão na base do neocolonialismo. Numa primeira instância, a mulher indígena está entregue à dominação cultural, à violência física ou psíquica, que são formas de horror. Para ela, há o mundo da tribo e o da cidade. $\mathrm{O}$ resultado é o esfacelamento da maneira como ela se representa nesses dois universos. A jovem protagonista do texto de Márcio de Souza, Izabel Pimentel, tem em comum a trajetória de outras mulheres indígenas em relação à violência e de variadas formas de dominação a que são submetidas, ou seja, há um intrincado mecanismo de regulação de poderes que articulam, 
desarticulam e depois rearticulam o espaço que as mulheres podem ocupar, mantendo, assim, a dinâmica política e histórica da ação colonizadora.

Em sociedades indígenas, essa formação é seguida, quase sempre, por uma violenta e gradual deformação. A narrativa A caligrafia de Deus (2007) expõe o tipo de formação discursiva do sujeito em relação ao processo de interação com os micros poderes que regem tal estatuto, não apenas individualmente, mas coletivamente.

O sujeito só é possível como performatividade de gênero. As relações de poder vêm, a seguir, como consequência do embate inicial. Suas leis e normas só funcionam a partir da diferenciação discursiva sobre o gênero. E é partindo dessa genealogia que o horror da dupla dominação da figura da mulher indígena se manifesta, dominação que é resultado do duplo poder colonial exercido sobre ela.

A noção de cultura destacada por Homi Bhabha (2013), Edward Said (2011) e Stuart Hall (2013) não pode ser pensada de forma binária e imutável. As construções identitárias das mais variadas construções de subjetividade atendem, em geral, pelo signo do provisório, do dispersivo, é o signo da fratura do catálogo biologizante, da categorização hierárquica, deixando pelo caminho os diversos "rastros" responsáveis pelas produções identitárias da contemporaneidade. Para os pensadores do multiculturalismo mencionados, não há mais validade possível para uma noção de cultura que ignore a si mesmo como fruto de longas e diversas formas de alteridade. $O$ que se verifica nas crises envolvendo tentativas de homogeneizar culturas ou de estabelecer parâmetros confiáveis para distinguir uma cultura de outra é o exercício das guerras e conflitos nos mais diferentes lugares, como foi o caso da Sérvia, do Iraque e, mais recentemente, os conflitos envolvendo o convívio entre sociedades muçulmanas e cristãs em território europeu.

A presença do colonizador em solo amazônico seguiu os mesmos conflitos que se verificou nos colonialismos europeus em territórios ultramarinos. O curioso é que, na pósmodernidade, a crise da cultura como valor estanque atinge de igual modo culturas tão díspares quanto os libaneses em Manaus ou os índios cristianizados.

O resultado parece se repetir na imposição de valores de um dos lados, nas diferentes formas de opressão neocolonialista que ignoram a possibilidade de integração com a cultura do outro sem que haja perda de identidade por parte do colonizador. Quando se pensa na personagem como Izabel Pinheiro, em A caligrafia de Deus (2007), índia submetida à violência paterna e, posteriormente, como forma de fuga, se desloca para Manaus em busca do estilo de 
vida que lhe foi introduzido por missionários cristãos por meio dos preceitos religiosos que pregam, sobretudo, a igualdade entre todos os filhos de Deus.

O resultado será uma nova sequência de violência. Ainda, a violência física da prostituição. Seu efeito psíquico é a virulência de como o horror da dominação que separa o "nós" do "deles", tendo como resultado o assassinato da índia e do seu namorado, caboclo, exribeirinho e traficante de bugigangas em Manaus. O que importa é que ambos são resultados da diáspora tematizada no horror da dominação do outro, como gênero e caráter performático do paroxismo da dinâmica neocolonialista. Nesse sentido, as palavras de Edward Said (2011) ilustram bem tal posição:

[...] uma outra intrigante analogia, as possessões imperiais estão lá, utilmente anônimas e coletivas, como populações párias (...) de diaristas, empregadas de meio período, artesãos sazonais; sua existência sempre conta, mas seus nomes e identidades não: são lucrativas sem estar inteiramente ali. É um equivalente literário, nas palavras um tanto ufanistas de Eric Woolf, do "povo sem história", do qual dependem a economia e a política sustentadas pelo império, mas cuja realidade não demandou, histórica ou culturalmente, maiores intenções (SAID, 2011, p. 119).

Nessa perspectiva, A caligrafia de Deus (2007), de Márcio Souza, pode ser caracterizada como uma narrativa sobre a diáspora moderna. $\mathrm{O}$ enredo in media res, técnica narrativa que se inicia numa parte já avançada da história e depois recua em vários flashbacks que, de certo modo, completa o hiato da narrativa não-linear, presentifica a ação, reforçando o recurso da poesia épica, desde Homero. É uma forma de narrar que une o antigo poema épico e seu substituto na história da literatura, o romance.

Retornando à narrativa de Márcio de Souza, a história inicia com os dois protagonistas já mortos, assassinados pela polícia após uma “varredura” no bairro Japiim de Manaus, próxima ao recém-inaugurado Distrito Industrial. A história se passa entre as décadas de 60 e 70 e nos dão um panorama bastante contundente do processo de explosão demográfica da cidade por conta da instalação das indústrias na região e a falta de perspectiva de trabalho no interior do estado, causando um êxodo extraordinário para a região. Como o assassinato dos dois jovens é absolutamente irrelevante, já que Alfredo, apelidado de Catarro, e Izabel, apelidada de Índia Potira, não passam de personagens que abandonaram os lugares de origem em busca de uma vida melhor em Manaus, encontrando um cenário caótico, onde as identidades sociais, as lembranças pessoais são reduzidas a pó, em um emaranhado de violência e extrema pobreza. 
Nessa esteira, a identidade do sujeito pós-moderno é crivada pelos signos da contradição e do efêmero. Além disso, é possível notar que o sujeito de tal natureza se constitui como performatividade, ou seja, não é composto por uma identidade, mas por diversas combinações, todas móveis, cambiantes e que se alteram segundo o contexto cultural do local de performatividade. Izabel, por exemplo, assemelha-se a um títere, pois passa pela aculturação do mundo-aldeia, é cristianizada, perde contato com a língua original e passa a fantasiar sobre o mundo "civilizado", sobre o "beijo" e a idealização das relações amorosas do mundo ocidental. Essa forma de dominação se dá pela linguagem e o fato de que a própria linguagem cria mecanismos de biopoderes que estão enovelados nos processos que tentam normatizar práticas de comportamento aceitáveis ou distópicas, fixá-las conforme se entende o modo de ser adequado ao conjunto cultural e não o modo de ser do "outro". O indivíduo já fragmentado é reconhecido como a diferença, e é essa assimetria a verdadeira responsável pela morte de Izabel, ou seja, a identidade só pode ser compreendida em sua conexão imediata com o que se produz a partir da noção de discordância.

A noção de diáspora é uma das ideias centrais dos estudos pós-coloniais e não pode ser entendida simplesmente como relação de um não pertencimento aliado ao concomitante desejo de retorno à origem. Embora cruciais para aquele que se vê entregue à dispersão do mundo moderno, não é algo que se limite aos problemas de retorno, regresso que, do ponto de vista geográfico, não é realmente difícil. A dificuldade, ou provavelmente o impossível, é o retorno para àquilo que poderia se chamar de identidade originária.

Stuart Hall (2013, p. 29), partindo de sua própria experiência e de seus compatriotas, comenta "a impossibilidade de retorno como algo definitivo". A sensação incômoda que o deslocamento proporciona de não se sentir em casa pode ser vista, não como limitação a ser superada pela ideia de origem e de retorno, mas sim arma contrária a opinião de cunho biologizante que essa mesma ideia traz consigo. Para Hall (2013), é uma questão que necessita ser repensada, sobretudo, do ponto de vista alternativo ao biológico, a alternativa cultural.

[...] essencialmente, presume-se que a identidade cultural seja fixada no nascimento, seja parte da natureza, impressa através do parentesco e da linhagem dos genes, seja constitutiva de nosso eu mais interior. É impermeável a algo tão "mundano", secular e superficial quanto uma mudança temporária de nosso local de residência. A pobreza, o subdesenvolvimento, a falta de oportunidades - os legados do Império em toda parte - podem forçar as pessoas a migrar, o que causa o espalhamento - a dispersão. Mas cada disseminação carrega consigo a promessa do retorno redentor (HALL, 2013, p. 30-31). 
Abordar a questão do pós-colonialismo significa, então, reconhecer que, mesmo diante de um fato histórico, desnorteante desde a iniciática visagem, e epistemologicamente controverso desde a primeira aproximação teórica. Ainda assim, se constitui em uma série gigantesca de características e associações desencarreiradas em relação ao passado recente, sugerindo de antemão, que o tema é delimitar um campo seguro de análise no espaço problemático que separa o oceano do Ocidente com o oceano do Oriente.

[...] A significação mais ampla da condição pós-colonial reside na consciência de que os "limites" epistemológicos daquelas ideias etnocêntricas são também as fronteiras enunciativas de uma gama de outras vozes e histórias dissonantes, até dissidentes - mulheres, colonizados, grupos minoritários, os portadores de sexualidades policiadas. Isto porque a demografia do novo internacionalismo é a história da migração pós-colonial, as narrativas da diáspora cultural e política, os grandes deslocamentos sociais de comunidades camponesas e aborígenes, as poéticas do exílio, [...]. É nesse sentido que a fronteira se torna o lugar a partir do qual algo começa a se fazer presente em um movimento não dissimilar ao da articulação ambulante, ambivalente [...] do além... (BHABHA, 2013, p. 24-25).

Nessa perspectiva, O primeiro cadáver nomeia um dos três capítulos de A Caligrafia de Deus (2007). A maestria de Márcio Souza se mostra no modo como divide o conto aproximando-o do que seria um épico, nesse caso, um épico trágico, mas sem poesia - sua forma de narrar é quase sempre muito jornalística, bem ao estilo de autores como Truman Capote ou Ernest Hemingway, - enquanto que os heróis do conto representam uma espécie de paródia do épico. O título desse capítulo se refere à irônica trajetória de Izabel Pimentel e de quase todos os habitantes de Iauretê-Cachoeira.

A história de Izabel Pimentel, uma índia baniwa, poderia ser a narrativa de qualquer outra jovem índia do interior. Durante o ano letivo, ela vive numa escola salesiana na cidade Iauretê-Cachoeira. No período de férias, retorna para sua aldeia. O pai, Pedro Pimentel, era um índio baniwa que passava os dias deitado em uma rede bebendo álcool com água e coçando os incontáveis bichos de pé que deixavam suas pernas sempre inchadas. A única diversão do velho índio, de 37 anos, era espancar sua mulher, uma índia tukano, duas vezes por ano. Os espancamentos aconteciam em duas festividades do ano: o Natal e o dia de Nossa senhora Auxiliadora.

Essas sessões de espancamentos geralmente terminavam com um dos dedos da mãe de Izabel quebrado. A relação entre os dias santificados pela igreja católica e as agressões que a mãe de Izabel sofria nas mãos do pai, demonstram o tom irônico e trágico que perseguirá 
também o destino da filha, como se fosse uma duplicação psicótica - a foraclusão ${ }^{3}$ - do destino das duas mulheres pela ação do pai, em todas as formas que a figura paterna possa assumir no destino trágico de mãe e filha.

Nesse caminho, a relação que identifica na narrativa o destino da mãe e da filha pode ser percebido, de antemão, por meio da chamada "ausência de inscrição" para as duas mulheres. A mãe de Izabel não tem nome, é apenas uma índia baniwa, possui 37 anos, seios murchos à mostra, usa sempre uma saia azul e o pouco de dinheiro que consegue é com a venda de ovos.

Izabel Pimentel, como já foi mencionado, carrega um sobrenome que pertence à imensa maioria das pessoas nascidas na pequena cidade de Iauretê-Cachoeira, ou seja, elas não existem como mulheres, são sujeitos desterritorializados. O significado da existência não pode ser justificado pela inscrição do nome porque isto inviabilizaria a imagem que deve existir por si nas margens: o simulacro de uma imagem borrada, sem fundo, sem, contudo, o significado do nome, que deveria existir, está apagado. Bastante alheia às humilhações a que é submetida, em Manaus, Izabel Pimentel terá diversos "nomes". Na Zona Franca será “a moça dos peitinhos em forma de cuia"; depois, como prostituta, será "Índia Potira" para uns e "Calcinha de Limão" para Catarro, seu namorado. Nesse sentido, de acordo com as ideias de Segato, a existência de Izabel Pimentel é uma linha constante de anonimato.

[...] uma foraclusão idiossincrática do nome - da mãe - na linha em que Judith Butler amplia o conceito lacaniano de foraclusão, [...]. De outra forma esta foraclusão do - nome da mãe - poderia ser descrita de forma mais ortodoxa e concordante com a interpretação lacaniana da psicose como foraclusão (psicótica) do nome do pai, em este caso numa falência específica da metáfora paterna: sua incumbência de nomear e gramaticalizar a mãe (SEGATO, 2006, p. 04).

Uma personagem como Izabel já entra no mundo com suas linhas traçadas pelo signo da tragédia. E é da mãe, no entanto, que Izabel recebe a ironia maior, trata-se de um conselho que a mãe lhe oferece e ela o guardará como o único detalhe realmente válido na figura da mãe: a máxima que ela sempre repetia para si e para Catarro: "De que Deus escreve certo por linhas tortas”. Se isto é que se enxerga como linhas tortas, é válido para o destino de todos os indivíduos. Nesse caminho, a conclusão de Segato é salutar para todas as Izabéis:

\footnotetext{
${ }^{3}$ É uma hipótese criada por Lacan para explicar a ausência do significante Nome-do-Pai na cadeia significante e no lugar do Outro. Essa hipótese, que estaria na base da estrutura psicótica, indica seu mecanismo de defesa. Nesse caso, a psicose seria definida pela não inscrição desse significante que é o responsável pela possibilidade de significação (BARBOSA, 2019, p. 57).
} 
[...] cada sociedade tem sua forma de racismo. Como afirmei em outras ocasiões, acredito que no Brasil esta operação cognitiva e afetiva de exclusão e violência não se exerce sobre outro povo, mas emana de uma estrutura alojada no interior do sujeito, plantada aí na origem mesma de sua trajetória de emergência (SEGATO, 2006, p. 14).

Com a morte do pai e o término do Ensino Fundamental, a jovem índia é convencida pela Madre Lúcia, uma espanhola, a substituir seus dentes amarelados de índia por um belo par de próteses com fileiras de dentes tão brancos e perfeitamente afilados quanto àqueles das revistas que exibiam casais apaixonados se beijando. A ideia do "beijo romântico" se torna tão obsessiva para Izabel quanto à ideia da madre de tornar os dentes da menina de feições précolombiana em dentes brancos: "Para alegria de Madre Lúcia ela deu início ao processo de transformar sua boca de bugre em boca de gente. Cada dente extraído daí para frente era como se deixar levar mais uma vez pela exótica maneira de Deus de riscar no mundo a sua sina" (SOUZA, 2007, p. 32).

A fixação de Izabel se voltava totalmente para a ideia do beijo e a dor da extração dos dentes certamente não seria obstáculo para o resultado final glorioso, que deixaria com inveja todas as outras meninas da aldeia:

[...] as meninas [da escola salesiana] gostavam de ficar admirando as fotografias dos beijos espetaculares e cismavam muitas horas sobre esse esquisito costume dos pares românticos das grandes cidades que externavam sua paixão encostando lábios contra lábios. $\mathrm{O}$ beijo não era uma instituição comum no Rio Negro e por isso mesmo as meninas ficavam muito assanhadas, loucas por uma experiência prática (SOUZA, 2007, p. 26).

O resultado não saiu como esperado por Izabel, pois os dentes pareciam saltar da boca. E não houve nenhum pretendente, os rapazes comentavam entre si que a jovem podia ficar com a boca murcha a qualquer momento, como uma velha, com a boca totalmente vazia. Izabel então decide aceitar outra oferta da Madre espanhola: se mudar para Manaus. Finalmente poderia beijar alguém e teria emprego como doméstica no Colégio Salesiano de Manaus. Se para a Madre Lúcia a oferta se convertia em mais um ato de caridade cristã, para Izabel, a oferta se converteria em uma sucessão interminável de trabalho não-remunerado. Há, no entanto, uma passagem em que Izabel é interpelada pelo padre Andreotti, pouco antes da decolagem do avião e, ao contrário da Madre, se opusera o tempo todo à troca dos dentes e à partida da jovem de sua aldeia. As palavras do sacerdote ficaram gravadas de modo confuso na memória da jovem: “Tomasse cuidado, que não se deixasse maltratar, que ela lembrasse que uma moça e cidadã 
que tinha direitos, mesmo sendo filha do falecido Pedro Pimentel, um índio baniwa" (SOUZA, 2007, p. 35).

Nesse caminho, em Os Condenados da Terra, Frantz Fanon (2002) também parece nos advertir para o perigo de que a relação de poder impressa no corpo de uma mulher - e de uma mulher duplamente subalterna - evidencia que não há apenas relações de força entre vencidos e vencedores, mas também trocas, com amplas relações culturais, mas que para o vencido, esta "troca" dificilmente se torna vantajosa. O que o padre provavelmente não ignora é que a identidade, por ser performática, só pode nos dar algum conforto se lembrarmo-nos de que é preciso fazer com que o processo de compartilhamento de valores e trocas culturais não faça desaparecer ou tornar desigual o contato. A violência contra Izabel é o símbolo da impossibilidade de erodir as estruturas hegemônicas que regem as vidas de todos os indivíduos. Nessa esteira, Fanon nos alerta para a verdadeira natureza da violência entre colonizador e colonizado:

O colonizado que decide realizar esse programa, que decide, que decide fazerse o seu motor, está preparado desde sempre para a violência. Desde o seu nascimento, está claro para ele que esse mundo encolhido, semeado de interdições, só pode ser questionado pela violência absoluta (FANON, 2005, p. 53).

O trabalho estafante na igreja salesiana é insuportável e logo Izabel foge e consegue um emprego na Zona Franca de Manaus como operária, um emprego que se mostra ainda mais estafante:

Era uma loucura para a Índia Potira, com sua dentadura, passar oito horas num cubículo iluminado a néon, com dois ventiladores que soltavam ar quente, entre divisões de grade de arame, soldando intermináveis transistores em circuitos impressos, ou adicionando pinos de plástico em envoltórios para fitas cassete. No fim do turno, todas as funcionárias passavam pelo setor de segurança, onde eram vistoriadas pelos guardas para ver se não estavam roubando nada. A Índia Potira não gostava nada de ter as mãos nojentas de um guarda qualquer apalpando seu traseiro todos os dias, só para saber se ela não teria enfiado um transistor no rabo (SOUZA, 2007, p. 37).

Não tardou para que a então Índia Potira abandonasse o emprego na Zona Franca por uma espelunca chamado providencialmente de "Inferno" e iniciasse sua carreira de prostituta e conhecesse Catarro, com quem estabeleceria uma espécie de relação amorosa "sem beijos".

Catarro, que também era do interior, de origem ribeirinha e ganhava a vida em Manaus com 
contrabando e venda ilegal de produtos roubados. Também era o alvo principal da polícia local, pois, mesmo que não representasse grande ameaça, sua eliminação seria o coroamento de uma ação policial efetiva e bem planejada, e que de fato fora levada a cabo, como mostra a cena de como os dois - Izabel e Catarro - foram encontrados mortos:

[...] [Isabel] devia ter uns vinte anos, estava vestida só de calcinha rendada cor de limão. O corpo estava em decúbito dorsal, como sairia nas matérias dos jornais. Uma mulher baixa, bem cheinha nas ancas, a cabeça com três furos de bala e o cabelo escuro marcado por placas de sangue coagulado. [...] $\mathrm{Na}$ parede, pendurados numa fileira de pregos, um vestido, um sutiã cor de limão, um retrato de Dom Bosco, outro vestido de tecido japonês que imitava brocado. A janela estava aberta e um soldado da PM tentava derrubar do mamoeiro, com uma vara muito flexível, um mamão todo picado por sanhaçus (SOUZA, 2007, p. 23).

O teor polifônico penetra na linguagem e nas ações de cada um deles. O que o narrador tenta, como se pretende analisar, é lidar com o dilema de que no mundo pós-colonial não há experiência transmissível que não seja provisória e fragmentada. O que se pode fazer frente ao caos gerados pela perspectiva das relações sociais entre dominantes e dominados é criar um espaço híbrido, capaz de dar sentido ao desafio de narrar a experiência do "outro" pelo viés da alteridade. Nesse sentido, o conselho do padre italiano ecoa e elabora um processo de escritura - no sentido derridiano - que põe em prática a forma de pensamento que parece ter como objetivo principal o desalojar-se de si mesmo, desabrigando, ao mesmo tempo, o sujeito produzido pelo silenciamento de outras dissoluções, como o passado da mãe e do pai de Izabel, que são também processos, que Michel Foucault $(2014 ; 1990)$ chamará de dessubjetivação na criação de uma linguagem que se desdobra sobre si mesma e sobre os filamentos deixados por outras linguagens.

\section{CONSIDERAÇÕES FINAIS}

A narrativa A Caligrafia de Deus (2007), de Márcio Souza, está perfeitamente inserida na concepção de mundo plural da pós-modernidade. O exercício do relato de experiências periféricas levado a cabo pelo narrador não restitui o passado. A tessitura do texto nada revela além do fato de que a única possibilidade redentora para a experiência contemporânea é lançarse rumo ao eterno vir-a-ser, no sentido de que a literatura contemporânea ignora os fatos em nome da perspectiva do inaudito, ou seja, do horror. Quando lançado sobre o real, a perspectiva 
do incomensurável e do inaudito estabelecem novos problemas para a aporia do real e da razão porque essas não são as únicas vias possíveis. Há, na proposta de vida de Izabel e Catarro uma forte relação com a impessoalidade que ruma para além do vazio do seu próprio corpo, mas também a busca de cativar para si o substrato que torna possível desconstruir a língua oficial “que Deus escreve certo por linhas tortas" em nome de uma língua estrangeira, primitiva, mas, ao mesmo tempo aglutinadora, cujos caminhos não são fechados, mas plurais.

Em nossa tarefa de discutir a dominação, o poder e a violência contra a mulher indígena, esses diferentes processos de subjetivação respondem de maneira dúbia, enviesada, não raramente contraditório. As questões que envolvem o problema do gênero estão na base do neocolonialismo e do poder de uma forma geral. Numa primeira instância, a mulher indígena está entregue à dominação cultural; na segunda, à violência física ou psíquica, que são as duas formas de horror possíveis em qualquer cultura. Para ela há o mundo da tribo e, em seguida, o da cidade. O resultado é o esfacelamento da maneira como ela se representa nesses dois mundos.

\section{REFERÊNCIAS}

BARBOSA, Keylla. Da Verwerfung em Freud à foraclusão em Lacan. Reverso [online]. 2019, v. 41, n. 77, p. 57-64.

BHABHA, Homi K. O local da cultura. Tradução de Myrian Ávila; Eliana Lourenço de Lima Reis e Gláucia Renate Gonçalves. Belo Horizonte: Editora UFMG, 2013.

BLASIUS, Mark. Gay and lesbian politics: sexuality and the emergency of a new ethic. Philadelphia: Temple University Press, 1994.

DERRIDA, Jacques. Gramatologia. Tradução de Mírian Chnaiderman e Renato Janine Ribeiro. São Paulo: Perspectiva, 2011.

DERRIDA. Jacques. A escritura e a diferença. Tradução de Maria Beatriz Marques Nizza da Sulva. São Paulo: Perspectiva, 2002.

FANON, Frantz. Os condenados da terra. Tradução de Enilce Albergaria Rocha e Lucy Magalhães. Rio de Janeiro: Editora da UFRJ, 2002.

FOUCAULT, Michel. História da sexualidade 2: o uso dos prazeres. Tradução de Maria Thereza da Costa Albuquerque. São Paulo: Editora Paz \& Terra, 2014.

FOUCAULT, Michel. As palavras e as coisas. Tradução de Salma T. Buchail. São Paulo: Martins Fontes, 1990. 
HALL, Stuart. Da diáspora: identidades e mediações culturais. Tradução de Adelaine La Guardia Et all. Belo Horizonte: Editora UFMG, 2013.

MATOS, Maria Izilda, S. de. Por uma história da mulher. Bauru-SP: EDUSC, 2000.

SAID, Edward, W. Orientalismo: o Oriente como invenção do Ocidente. Tradução de Tomás Rosa Bueno. São Paulo: Companhia das Letras, 2011.

SEGATO, Rita Laura. $O$ Édipo brasileiro: a dupla negação de gênero e raça. Brasília: Editora UNB, 2006.

SOUZA, Márcio. A caligrafia de Deus. São Paulo: Lazuli Editora: Companhia Editora Nacional, 2007. 